\title{
Distinctly different behavioral responses of a copepod, Temora longicornis, to different strains of toxic dinoflagellates, Alexandrium spp.
}

\author{
Jiayi Xu $\mathrm{u}^{\mathrm{a}, \mathrm{b}, *}$, Per Juel Hansen ${ }^{\mathrm{c}}$, Lasse Tor Nielsen ${ }^{\mathrm{a}}$, Bernd Krock ${ }^{\mathrm{d}}$, Urban Tillmann ${ }^{\mathrm{d}}$, \\ Thomas Kiørboe ${ }^{\mathrm{a}}$ \\ a Centre for Ocean Life, National Institute for Aquatic Resources, Technical University of Denmark, 2920 Charlottenlund, Denmark \\ ${ }^{\mathrm{b}}$ Key and Open Laboratory of Marine and Estuary Fisheries, Ministry of Agriculture of China, East China Sea Fisheries Research Institute, Chinese Academy of \\ Fisheries Sciences, 200090 Shanghai, China \\ ${ }^{\mathrm{c}}$ Marine Biological Section, University of Copenhagen, 3000 Helsingør, Denmark \\ ${ }^{\mathrm{d}}$ Alfred Wegener Institut-Helmholtz Zentrum für Polar- und Meeresforschung, 27570 Bremerhaven, Germany
}

\section{A R T I C L E I N F O}

\section{Article history:}

Received 19 August 2016

Received in revised form 29 November 2016

Accepted 29 November 2016

Available online $\mathrm{xxx}$

\section{Keywords:}

Feeding behavior

Paralytic shellfish toxins

Goniodomin A

Lytic activity

\begin{abstract}
A B S T R A C T
Zooplankton responses to toxic algae are highly variable, even towards taxonomically closely related species or different strains of the same species. Here, the individual level feeding behavior of a copepod, Temora longicornis, was examined which offered 4 similarly sized strains of toxic dinoflagellate Alexandrium spp. and a non-toxic control strain of the dinoflagellate Protoceratium reticulatum. The strains varied in their cellular toxin concentration and composition and in lytic activity. High-speed video observations revealed four distinctly different strain-specific feeding responses of the copepod during $4 \mathrm{~h}$ incubations: (i) the 'normal' feeding behavior, in which the feeding appendages were beating almost constantly to produce a feeding current and most (90\%) of the captured algae were ingested; (ii) the beating activity of the feeding appendages was reduced by ca. $80 \%$ during the initial $60 \mathrm{~min}$ of exposure, after which very few algae were captured and ingested; (iii) capture and ingestion rates remained high, but ingested cells were regurgitated; and (iv) the copepod continued beating its appendages and captured cells at a high rate, but after $60 \mathrm{~min}$, most captured cells were rejected. The various prey aversion responses observed may have very different implications to the prey and their ability to form blooms: consumed but regurgitated cells are dead, captured but rejected cells survive and may give the prey a competitive advantage, while reduced feeding activity of the grazer may be equally beneficial to the prey and its competitors. These behaviors were not related to lytic activity or overall paralytic shellfish toxins (PSTs) content and composition and suggest that other cues are responsible for the responses.
\end{abstract}

(c) 2016 Elsevier B.V. All rights reserved.

\section{Introduction}

Zooplankton plays a crucial role in marine food webs, both by channeling primary production to higher trophic levels and by controlling phytoplankton populations. Algal blooms occur when algal growth exceeds zooplankton grazing. Thus, harmful algal blooms are thought to be facilitated by reduced grazing due to the algae producing toxic substances (Jonsson et al., 2009) that, in turn, are believed mainly to function as grazer deterrents. Reported grazer responses to harmful algae are diverse. The responses of

\footnotetext{
* Corresponding author at: Centre for Ocean Life, National Institute for Aquatic Resources, Technical University of Denmark, 2920 Charlottenlund, Denmark.

E-mail address: sjxu@aqua.dtu.dk (J. Xu).
}

copepods, for example, to toxic algae may vary within and between species of both the grazers and algae, and responses range from unaffected to substantial (Turner, 2014). Even different populations of the same copepod species may show different responses to the same strain of a toxic alga due to acclimation or adaptation (Colin and Dam, 2002; Engström-Öst et al., 2002; KozlowskySuzuki et al., 2003). A further complicating factor is that different strains and natural populations of the same algal species may vary in their toxicity and with its growth conditions (Burkholder and Glibert, 2006; Cembella, 1998). With a few exceptions (e.g., Hong et al., 2012), only macroscopic responses (e.g. mortality and feeding rate) rather than behavioral responses are examined, and in most cases it is not possible to establish a mechanistic relationship between the algal toxin profile and its effects on the copepod grazer. 
The genus Alexandrium is found worldwide and is one of the most studied toxic dinoflagellates (Anderson et al., 2012). It includes 33 described species, of which 11 are known to produce paralytic shellfish toxins (PST) (Moestrup et al., 2009). The chemical structures of this group of toxins, including saxitoxin (STX) and approximately 57 derivatives, are well described from the genus and from seafood (Munday, 2014). Paralytic shellfish toxins are sodium-ion channel blockers that can cause potent neurotoxic syndromes in humans as well as fish, seabirds and marine mammals (Cembella, 1998; Turner and Tester, 1997; Turner, 2014). Reported effects on copepods offered PST-containing Alexandrium spp., however, range from none to adverse effects on ingestion rate, egg production, egg hatching and offspring development duration (Dutz, 1998; Frangopulos et al., 2000; Guisande et al., 2002). These variations in responses are not related to the overall toxicity of the cells (Teegarden et al., 2008) and raises the question of whether or not the PSP toxins actually function as a grazer deterrents. Could other compounds produced by Alexandrium spp. be responsible for the observed effects on copepods?

In fact, a number of different toxins have been found among Alexandrium spp. in addition to the PSTs, making interpretations of past reports difficult: spiroimines (spirolides, gymnodimines), goniodomin A and lytic compounds. The spiroimines are potent fast-acting neurotoxins that have so far only been found in the European and North Atlantic A. ostenfeldii but not Baltic A. ostenfeldii (Kremp et al., 2014; Sopanen et al., 2011). Goniodomin $A$ is also a neurotoxin that has been reported to affect vertebrates (Klein et al., 2010) as well as invertebrates (Murakami et al., 1988). This toxin has only been reported for $A$. hiranoi, A. monilatum and $A$. pseudogonyaulax (Hsia et al., 2006; Murakami et al., 1998, 1988) and these species do not produce PSTs. Finally, many Alexandrium species and strains also have the ability to produce extracellular allelochemical compounds, which are still poorly examined chemically (Ma et al., 2009). These extracellular allelochemical compounds have been demonstrated to affect protistan grazers (Legrand et al., 2003; Tillmann and John, 2002), competitors (Granéli and Hansen, 2006; Legrand et al., 2003; Tillmann and Hansen, 2009), or paralyze prey cells (Blossom et al., 2012), while effects on metazoan grazers are still unknown. Thus, studies using experimental and control Alexandrium strains characterized as PST and non-PST strains might be misleading, as they may differ substantially in the presence/absence of other toxins/bioactive compounds.

Here, authors examined the initial behavioral response of the copepod Temora longicornis to 3 different strains of Alexandrium tamarense, a single strain of $A$. pseudogonyaulax and to a strain of Protoceratium reticulatum that contains no known toxins. Species and strains were selected due to their similar size and shape but different toxin content and profile (PSTs, lytic activity of the cells, Goniodomin A). Direct, high-speed video was used to describe feeding behaviors (activity, prey capture, rejection, ingestion, regurgitation). A wide prey-specific behavioral repertoire of the copepods were demonstrated that lead to a variation of ingestion rate and with distinctly different implications to the prey and their ability to form blooms. The behavioral response was unrelated to the composition or content the compounds analyzed for the $A$. tamarense strains, suggesting that other compounds may trigger the avoidance behavior observed towards some of the prey.

\section{Materials and methods}

\subsection{Algal cultures}

A strain of Protoceratium reticulatum and 4 clonal strains of Alexandrium spp. were used in the experiments (Table 1). The culture of $P$. reticulatum CCMP1889 obtained from National Center for Marine Algae and Microbiota, A. pseudogonyaulax CAWD138 obtained from Cawthron Institute, and $A$. tamarense Alex2, A. tamarense Alex5, and A. tamarense AlexH5 obtained from Alfred Wegener Institute. The different algae were of similar size but varied in their toxin profiles (Tables 1 and 2). Algal cultures were maintained on B1 medium prepared with pasteurized, filtered sea water at $16^{\circ} \mathrm{C}$ and a salinity of 32 . The cultures were exposed to an irradiance of $150 \mu \mathrm{mol}$ photons $\mathrm{m}^{-2} \mathrm{~s}^{-1}$ on a $12 \mathrm{~h}$ : $12 \mathrm{~h}$ light: dark cycle. All phytoplankton used in the experiments were in exponential growth.

\subsection{Toxin analyses}

Paralytic shellfish toxins and lytic activity of the cells were quantified. Meanwhile, the presence of goniodomin $\mathrm{A}$, and yessotoxins (YTX) were tested. For cell content analyses, 10 to

Table 1

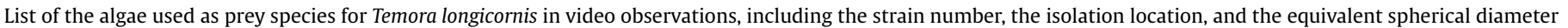
(ESD).

\begin{tabular}{|c|c|c|c|c|}
\hline Algae & Strain & Origin & $\mathrm{ESD} \pm \mathrm{SD}(\mu \mathrm{m})$ & Reference \\
\hline Protoceratium reticulatum & CCMP1889 & Friday Harbor, USA & $32.0 \pm 2.3$ & (Howard et al., 2009) \\
\hline \multirow{3}{*}{ Alexandrium tamarense } & Alex2 & North Sea off Scotland & $31.3 \pm 2.5$ & (Tillmann and Hansen, 2009; Tillmann et al., 2009) \\
\hline & Alex5 & North Sea off Scotland & $33.8 \pm 0.5$ & (Tillmann and Hansen, 2009; Tillmann et al., 2009) \\
\hline & AlexH5 & Gulf of San Jorge, Argentina & $31.6 \pm 0.7$ & (Krock et al., 2015) \\
\hline Alexandrium pseudogonyaulax & CAWD138 & Kerikeri, New Zealand & $33.8 \pm 0.9$ & \\
\hline
\end{tabular}

Table 2

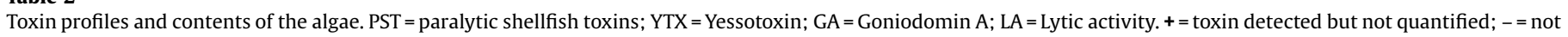
detected.

\begin{tabular}{|c|c|c|c|c|c|c|c|c|c|c|c|c|}
\hline \multirow[t]{2}{*}{ Algae } & \multirow[t]{2}{*}{ Strain } & \multicolumn{7}{|c|}{ PSTs (fmol cell ${ }^{-1}$ ) } & \multirow{2}{*}{$\begin{array}{l}\text { Cell Toxicity } \\
\left(\text { pg STXeq cell }{ }^{-1}\right)\end{array}$} & \multirow[t]{2}{*}{ YTX } & \multirow[t]{2}{*}{ GA } & \multirow{2}{*}{$\begin{array}{l}\mathrm{LA} \mathrm{LC}_{50} \\
\left(\text { cells } \mathrm{ml}^{-1}\right)\end{array}$} \\
\hline & & $\mathrm{C} 1 / \mathrm{C} 2$ & GTX1/4 & dcGTX $2 / 3$ & GTX2/3 & NEO & STX & total & & & & \\
\hline Protoceratium reticulatum & CCMP1889 & 0.0 & 0.0 & 0.0 & 0.0 & 0.0 & 0.0 & 0.0 & 0.0 & - & - & - \\
\hline \multirow[t]{3}{*}{ Alexandrium tamarense } & Alex2 & 4.7 & 0.0 & 0.0 & 0.4 & 4.2 & 2.1 & 11.4 & 2.3 & - & - & 511 \\
\hline & Alex5 & 43.0 & 40.6 & 2.3 & 3.9 & 27.5 & 10.8 & 128.1 & 29.1 & - & - & - \\
\hline & AlexH5 & 119.5 & 40.1 & 0.1 & 2.9 & 8.5 & 0.0 & 171.0 & 22.9 & - & - & 544 \\
\hline Alexandrium pseudogonyaulax & CAWD138 & 0.0 & 0.0 & 0.0 & 0.0 & 0.0 & 0.0 & 0.0 & 0.0 & - & + & - \\
\hline
\end{tabular}


$20 \mathrm{ml}$ of exponentially growing Alexandrium spp. and P. reticulatum cells (around 2000 cells ml $^{-1}$ ) were centrifuged $(2150 \times \mathrm{g}, 15 \mathrm{~min})$. After removing most of the supernatant, the algae were re-suspended in $1 \mathrm{ml} \mathrm{B1}$ medium and transferred to a microcentrifuge tube. Samples were centrifuged again at $3200 \times g$ for $15 \mathrm{~min}$. All the supernatant was removed. The dry cell pellets were kept at $-20^{\circ} \mathrm{C}$. Both cell concentrations of the initial algal culture and the supernatant were enumerated to calculate the exact number of cells in the pellets for toxin analysis.

Paralytic shellfish poisoning toxins (PSTs) were extracted with $500 \mu \mathrm{l} 0.03 \mathrm{mM}$ acetic acid by ultrasonication (sonotrode HD 2070, Bandelin, Berlin, Germany; 1 min, cycle time $50 \%, 10 \%$ power). The samples were centrifuged at $16,100 \mathrm{xg}$ and supernatants filtered over centrifugation filters (pore-size $0.45 \mathrm{~mm}$, Millipore Ultrafree, Eschborn, Germany) at $1,500 \mathrm{x}$ for $30 \mathrm{~s}$. filtrates were transferred to autosampler vials and measured by ion-pair liquid chromatography coupled to post-column derivatization and fluorescence detection as described in detail in Suikkanen et al. (2013). In order to make the data comparable to other literature values, the combined cell toxicity was calculated as saxitoxin equivalents (STXeq) by multiplying toxin concentration values from HPLC chromatograms by toxin-specific toxicity equivalency factors (TEFs, Alexander et al., 2009) Since dinoflagellates are believed to exclusively produce the betamers of enantiomeric pairs (Cembella, 1998) and the corresponding alphamers are regarded as extraction artifacts, only TEFs of the betamers were used to calculate total toxicity as STX equivalents.

Lipophilic toxins (YTX and goniodomin A) were extracted with $300 \mu \mathrm{l}$ methanol and analyzed for YTX as described in detail in Sala-Pérez et al. (2016). All lipophilic extracts were also screened for two pseudomolecular ions of gonodomin $\mathrm{A}$ in the positive mode: $m / z 786\left(\left[\mathrm{M}+\mathrm{NH}_{4}\right]^{+}\right)$and $m / z 791\left([\mathrm{M}+\mathrm{Na}]^{+}\right)$that were reported by Hsia et al. (2006). For the positive samples product ion spectra of both pseudomolecular ions were also recorded.

To quantify allelochemical (lytic) activity, the method of Blossom et al. (2014) was used, in which the concentration of dinoflagellate cells that cause 50\% mortality of target cells (Teleaulax acuta) is determined (Table 2 and Appendix Fig. 1). A target cell concentration of 3250 cells $\mathrm{ml}^{-1}$ and relative fluorescence were used to quantify target cell concentration. Vials with target cells and 10 to 15 different concentrations of supernatant obtained after centrifugation $(2150 \times \mathrm{g}, 15 \mathrm{~min})$ of dinoflagellate cultures were placed at $16^{\circ} \mathrm{C}$ in the dark for $3 \mathrm{~h}$, at which time target cell survival was quantified flourometrically (TD-700 Fluorometer, Turner Designs, San Jose, California, US).

\subsection{Copepod feeding behavior}

A feeding-current feeding copepod, Temora longicornis, were isolated from the Øresund, Denmark, and used to establish a continuous culture at $16^{\circ} \mathrm{C}$, salinity 32 . The culture was fed a mixed phytoplankton diet including Akashiwo sanguinea, Heterocapsa triquetra, Prorocentrum minimum, Thalassiosira weissflogii, and Rhodomonas salina.

Adult females used for video experiments were tethered to the dorsal surface with a short length of human hair using a small drop of super glue (Cowles and Strickler, 1983) and placed overnight in filtered sea water in a dark, thermo- constant room $\left(16^{\circ} \mathrm{C}\right)$. The subsequent morning, the other end of the hair was attached to a micromanipulator and the copepod was placed in a $10 \times 10 \times 10$ $\mathrm{cm}^{3}$ transparent container filled with filtered sea water in a thermo- constant room. The tethered copepods may live for many days and appear unaffected by the tether.

Phytoplankton was added at time 0 , and the behavior of the copepod recorded during the subsequent $4 \mathrm{~h}$. Copepods were offered one of the four strains of Alexandrium spp. or P. reticulatum at one of 3 different concentrations (40,80 and 200 cells $\left.\mathrm{ml}^{-1} ; \pm<10 \%\right)$. Three individual copepods were tested for each strain/concentration treatment, totaling 9 individuals per strain. Samples $(3 \mathrm{ml}$ ) for algal enumeration were removed during the beginning, middle and end of filming to check the prey concentrations. Also, the water was gently stirred throughout the experiment to prevent sedimentation of the algae. The tethered copepod was filmed with a Phantom V210 high speed camera using infrared illumination shined through the aquarium towards the camera. The camera was equipped with Nikon lenses to yield a field of view of approximately $2.5 \times 1.6 \mathrm{~mm}^{2}$ (varied slightly between experiments). Both high speed (resolution: $1280 \times 800$ pixels; frame rate: $2200 \mathrm{~Hz}$ ) and low speed (resolution: $720 \times 576$ pixels; frame rate: $25 \mathrm{~Hz}$ ) videos were saved simultaneously from the camera. The low speed video was set to save automatically the first $30 \mathrm{~min}$ and then for 10 min every $1 / 2$ hour to describe feeding activity and prey interactions. Several $2.5 \mathrm{~s}$ sequences of high speed recordings were saved through the entire experimental duration to quantify appendage beat frequencies and describe prey response behaviors.

The feeding current of $T$. longicornis is created by the regular beating of the second antenna (A2) and the maxillipeds (MXP) as well as of the other feeding appendages (Gonçalves et al., 2014; Paffenhöfer et al., 1982; Tiselius et al., 2013) (Appendix Video 1). When a prey particle within the feeding current touches the setae on one of the feeding appendages and is detected, the regular beating of the feeding appendages is changed to guide the prey particle next to mandibles. An event as a 'capture' was classified when the prey particle was handled by the copepod (Appendix Video 1). After being captured, the prey was generally handled for a short period and adjusted to a certain position before either being swept into the mouth, an 'ingestion' event (Appendix Video 1), or being rejected (a 'rejection' event; Appendix Video 2). In some cases, all or parts of a prey particle were regurgitated after ingestion, which was recorded as both 'ingestion' and 'regurgitation' events (Appendix Video 3).

The low speed recordings were used to enumerate capture, ingestion, rejection, and regurgitation events and to quantify the fraction of time the animal was beating its feeding appendages. The fraction of time beating was estimated by counting the number of frames that the copepod was beating its appendages during the last $1 \mathrm{~min}$ of every $10 \mathrm{~min}$ sequence.

The high speed video was used mainly to quantify the beat frequency of the appendages. Characteristic sequences were also saved to illustrate the various types of feeding behaviors (Appendix Video 1-4). Prey positions and beating frequencies were measured using ImageJ (Version 1.48; National Institutes of Health, USA) and Phantom Cine Viewer (Version 2.6; Vision Research).

Waterborne cues from copepod grazers can induce increased PSTs production in Alexandrium spp. (Selander et al., 2006), but the full induction takes 2-4 days (Selander et al., 2012), and is low with the low concentration of copepods used here ( 1 per $800 \mathrm{ml})$. Thus, it is assumed that the chemical profile of cells from the culture is representative for the experiments.

\subsection{Statistical analysis}

Differences in appendage beat frequency, fraction of time beating, capture rate, ingestion rate, and fraction of captured cells rejected between treatments were tested using two-way ANOVA with prey concentration and prey species as factors. Mean values were compared using Holm-Sidak Test and carried out in SigmaPlot 13.0. Normality was tested according to Shapiro-Wilk. 


\section{Results}

\subsection{Algal toxin content}

6 different species of PSTs were identified (Table 2). Strain Alex5 contained mainly C1/C2, GTX 1/4, STX and NEO. AlexH5 also had high cell toxin content, but mainly C1/C2 and GTX $1 / 4$; it lacked STX. Strain Alex2 had fewer PST derivatives and an order of magnitude lower cellular PST content. A compound with the molecular mass of goniodomin A was only detected in A. pseudogonyaulax, which did not have PSTs. The strain of $P$. reticulatum contained neither YTX nor other toxins (lytic compounds, PSTs or goniodomin A) above detection level and hence worked as a non-toxic control.

2 strains of $A$. tamarense (Alex 2 and AlexH5) both produced and excreted compounds with lytic effects on the test organism T. acuta (Table 2).

\subsection{Appendage beat frequency}

The cephalic appendages of $T$. longicornis produce a continuous repetitive beating. The appendage beat frequency varied between
22 and $34 \mathrm{~Hz}$ between the 5 diets (Fig. 1A). The variation was independent of prey concentrations $(P=0.905)$, and time $(P=0.380$; data in Appendix Fig. 2), but differed significantly between prey $(\mathrm{P}<0.05)$. The beat frequency was highest $(33 \mathrm{~Hz})$ when fed on A. tamarense AlexH5 at all prey concentrations, while the beat frequencies of copepods exposed to the other four preys were similar to one another and averaged $26 \mathrm{~Hz}$. Time-resolved patterns in beat frequencies are given in Appendix Fig. 2.

\subsection{Fraction of time the feeding appendages beat}

Initially all the copepods were using their appendages constantly. Most of them kept beating at near $100 \%$ of the time during all 4 observation hours (Appendix Video 1-3), except copepods exposed to A. tamarense Alex5 (Appendix Video 4). With this prey, the beating activity of the copepods decreased rapidly during the first hour to reach about $20 \%$ of the time and then remained at that level during the remaining $3 \mathrm{~h}$ (Figs. $1 \mathrm{~B}$ and $2 \mathrm{~A}$ ). The decline was statistically significant $(p<0.05)$ but independent of prey concentration $(P=0.222)$. Since several aspects of the feeding behavior changed during the first hour but subsequently remained relatively stable, all the statistical analyses below
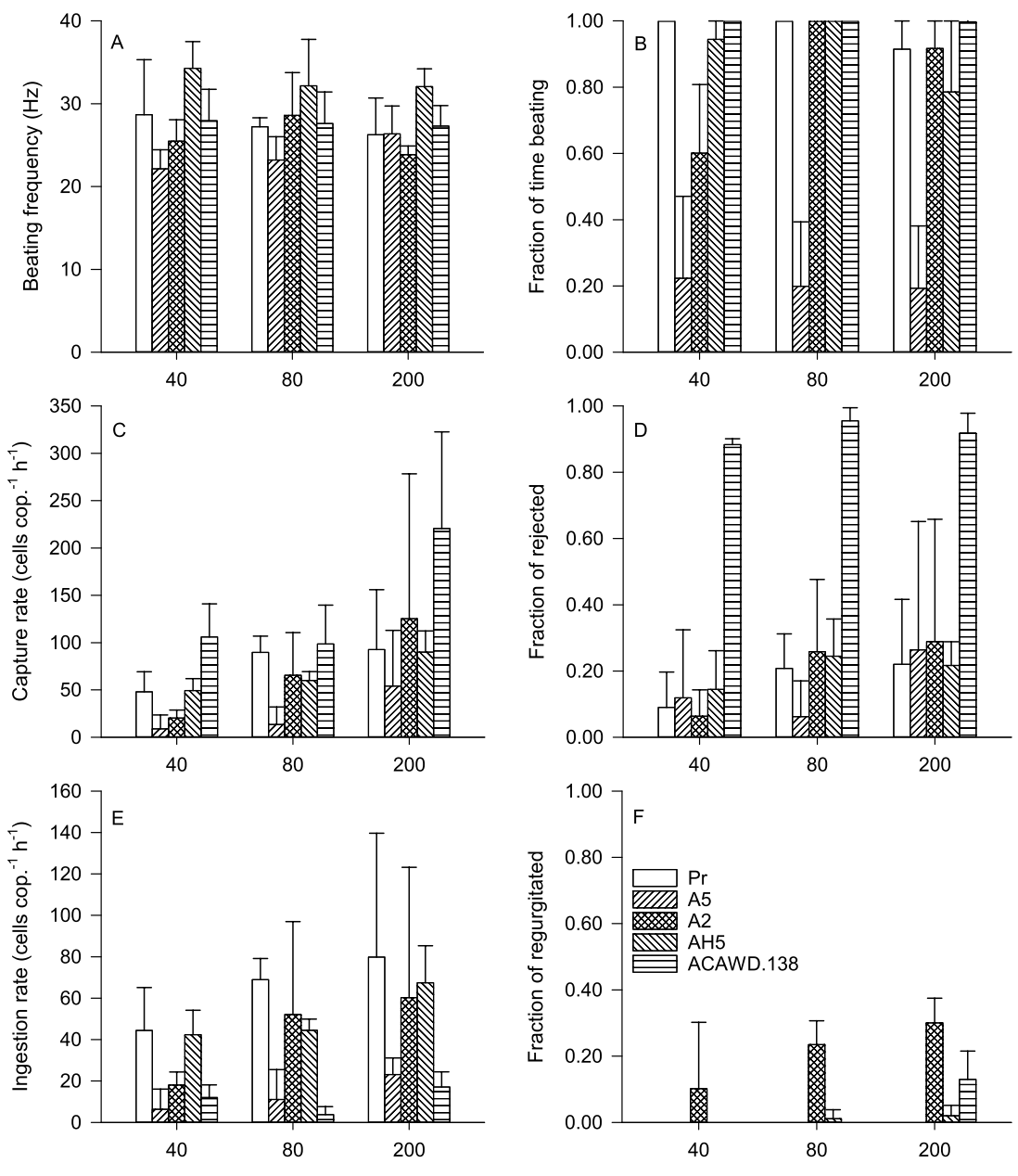

Prey concentration (cells $\mathrm{ml}^{-1}$ )

Prey concentration(cells $\mathrm{ml}^{-1}$ )

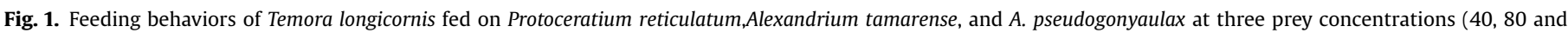

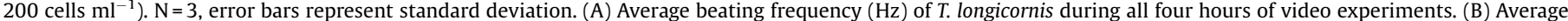

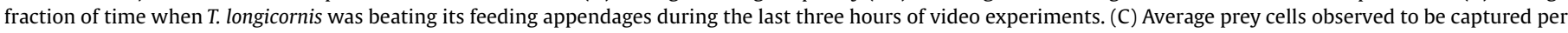

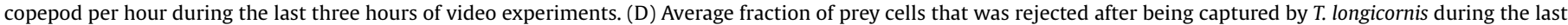

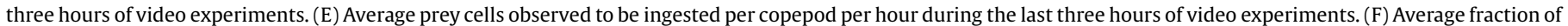
prey cells that was regurgitated after being ingested by $T$. longicornis during the last three hours of video experiments. 


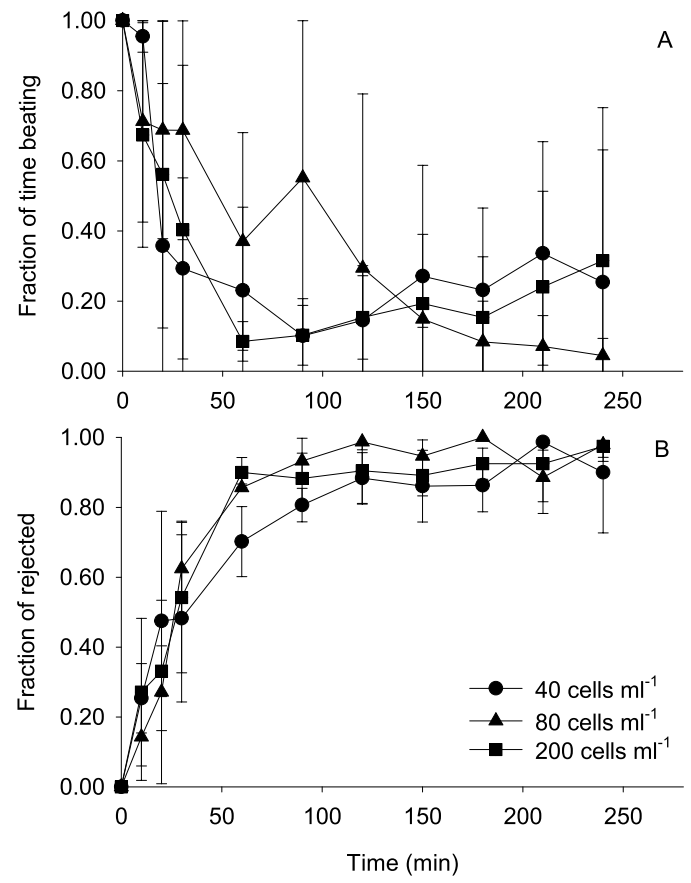

Fig. 2. Temporal behavioral variation of Temora longicornis fed Alexandrium spp during the four hours video experiments. (A) The fraction of time beating of $T$. longicornis fed on A. tamarense (Alex5) decreased independently of prey concentration. (B) The fraction of rejected of T. longicornis fed on A. pseudogonyaulax increased independently of prey concentration.

consider only the last $3 \mathrm{~h}$ of each experiment. Time resolved patterns in appendage activity are shown for all prey in Appendix Fig. 3.

\subsection{Capture rate}

Prey capture rate increased with increasing prey concentration for all prey types (Fig. 1C, time resolved in Appendix Fig. 4) and differed significantly between prey species and concentrations $(\mathrm{P}<0.05)$. With the same prey concentration, $A$. pseudogonyaulax were captured at the highest rate and $A$. tamarense Alex 5 at the lowest rate. The other strains were captured at intermediate and similar rates.

\subsection{Rejection}

Captured prey may be ingested or rejected. Initially, all copepods rejected only a small fraction $(\approx 20 \%)$ of captured cells. After $60 \mathrm{~min}$, the proportion of rejected A. pseudogonyaulax cells increased to $\approx 80 \%$ and remained at this level till the end of the observation period (Figs. 1D and 2B, Appendix Video 2, timeresolved pattern in Appendix Fig. 5). With the other four prey strains the fraction of rejected cells remained stable and low (Appendix Fig. 5). Thus, not including the first hour, the fraction of rejected cells was significantly higher with $A$. pseudogonyaulax $(0.9 \pm 0.1)$ compared to the four other prey strains $(0.2 \pm 0.1)$ $(\mathrm{p}<0.05)$, while prey rejection was independent of prey concentration for all five prey $(\mathrm{P}=0.152)$.

\subsection{Ingestion rate}

The ingestion rate of prey is the product of capture rate and the fraction of accepted (i.e., not rejected) cells. The ingestion rate increased with the increasing of prey concentration with all prey $(p<0.05)$, and there were also significant differences between prey strains $(\mathrm{P}<0.05)$ (Fig. 1E). Non-toxic control, P. reticulatum, cells were consistently ingested at the highest rate $\left(80 \pm 60\right.$ cells $^{-1}$ at 200 cells $\mathrm{ml}^{-1}$ ), and $A$. pseudogonyaulax and A. tamarense Alex5

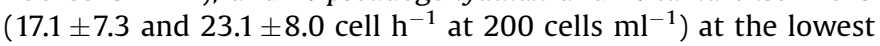
rates, with the other strains in between (time resolved in Appendix Fig. 6).

\subsection{Regurgitation}

Some ingested cells were rapidly (within $1 \mathrm{~s}$ ) regurgitated. This was in particular evident with A. tamarense Alex2 as prey (Appendix Video 3 ). The proportion of cells regurgitated increased with increasing $A$. tamarense Alex 2 concentration to more than $30 \%$ at the highest concentration (Fig. 1F and Appendix Fig. 7), but was independent of time $(P=0.670)$. A small proportion ( $2 \%$ and $13 \%$ ) of ingested cells was also regurgitated when copepods were fed a high concentration of A. tamarense AlexH5 and A. pseudogonyaulax, respectively.

\subsection{Ingestion of PSTs by the copepods}

Based on the ingestion and regurgitation of phytoplankton cells by copepods (Fig. 1) and the toxin content of each algal prey (Table 2), the total ingestion of PSTs (in STX equivalents) and STX on the three diets of $A$. tamarense were calculated (Fig. 3 and Appendix Fig. 8 -10). The cumulated amount of ingested PSTs increased over time and with cell concentration, and was highest in copepods offered AlexH5, and lowest when offered Alex2 (Fig. 3A). Due to a lack of STX in Alex H5, The highest accumulation of STX was in copepods offered Alex 5 and followed by copepods offered Alex2 (Fig. 3B).

\section{Discussion}

4.1. Repertoire of copepod feeding behaviors and implications to prey populations

4 distinctly different behavioral responses of the copepod were observed to various prey cells, viz.: (i) normal feeding behavior the feeding appendages are beating more or less constantly and most captured cells are ingested (control alga $P$. reticulatum and AlexH5); (ii) the copepod significantly reduces the fraction of time it is beating its appendages in the course of the first hour after introducing prey cells and beating activity then remains low; captured cells are however mainly ingested, although at a low rate (Alex5); (iii) appendage beat activity remains high and cells are captured and ingested at a high rate, but a large fraction of the ingested material is subsequently regurgitated (Alex2); and (iv) feeding activity and prey capture rate remains high, but an increasing fraction of captured cells are rejected during the first hour, and rejection rate remains high during the remainder of the observation period (A. pseudogonyaulax). Most previous studies of the response of copepods to toxic algae are incubation studies, in which the net outcome of the copepod-prey interaction is quantified in terms of feeding rate, prey selection, growth or egg production rate, or other similar bulk measures (reviewed by Turner, 2014). The direct video observation of individual responses and of direct copepod-prey cell interactions provided by this and a few other studies (Bruno et al., 2012; Hong et al., 2012; Tiselius et al., 2013) are innovative and allow us to disentangle the possible mechanisms underlying the diverse outcome of 'black box' incubation experiments and to better evaluate their ecological significance.

Several studies have reported that copepods may select between toxic and non-toxic cells in a prey mixture (DeMott and Moxter, 1991; Huntley et al., 1986; Schultz and Kiørboe, 2009; 

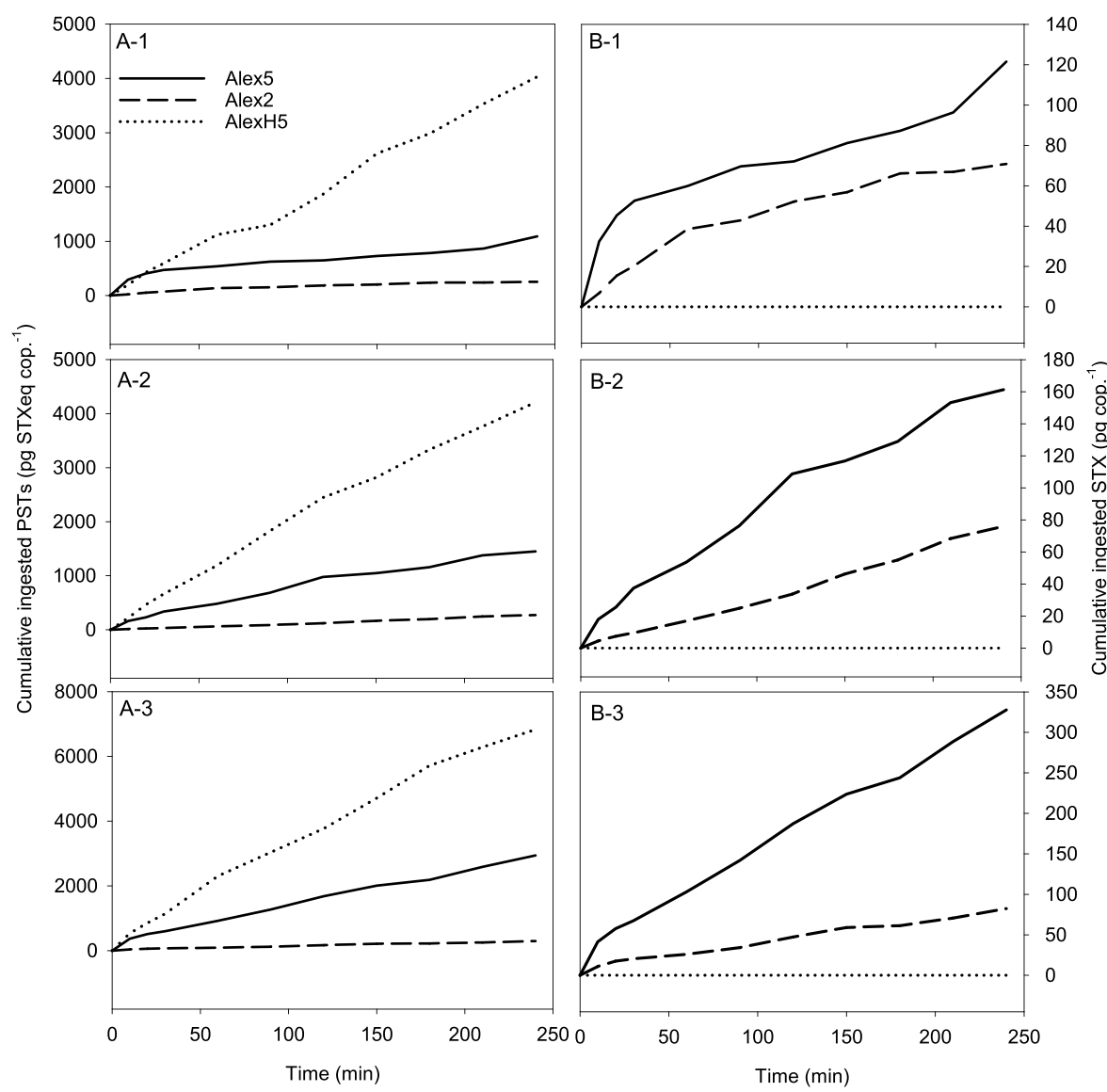

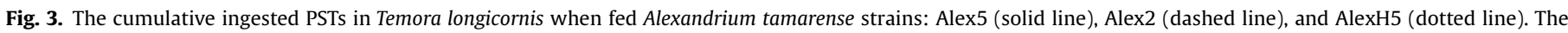

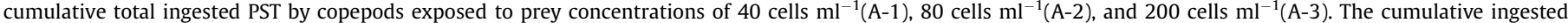
saxitoxin (STX) at prey concentrations of 40 cells ml $\mathrm{ml}^{-1}(\mathrm{~B}-1), 80$ cells ml $\mathrm{m}^{-1}(\mathrm{~B}-2)$, and $200 \mathrm{cells} \mathrm{ml}^{-1}(\mathrm{~B}-3)$. Values are means $(\mathrm{n}=3)$

Selander et al., 2006; Teegarden, 1999). The fact that the copepods can distinguish between cells of very similar size and shape suggests that selection is mediated by chemical information. Schultz and Kiørboe (2009) suggested that copepods possess the ability to remotely discriminate non-toxic and toxic algae before capture. Recently however the ability of copepods to remotely detect phytoplankton based on their chemical characteristics has been questioned (Gonçalves and Kiørboe, 2015), and our observations suggest that prey selection is based on post-capture discrimination and that unwanted cells are rejected following a handling time. Vanderploeg et al. (1990) reported a similar observation in a freshwater copepod. Thus, prey selection appears to be based on gustation (taste) rather than olfaction (smell).

Multiple studies have reported reduced feeding rates on toxic compared to similarly sized and shaped non-toxic algae in single-prey experiments (Turner, 2014), and our observations suggest two possible mechanisms behind such a response, i.e., rejection of captured cells before ingestion and reduced feeding activity. An increased cell rejection was observed only with A. pseudogonyaulax as prey, and the increasing rejection rate during the first hour, suggesting that the copepod would need to learn that these cells are un-wanted. The reduced feeding activity response (reduced appendage beat activity) was only observed with $A$. tamarense Alex5 as food. Since the lytic compounds detected from Alex H5 had no effect on the feeding behavior of $T$. longicornis, the extracellular compounds were not the trigger. The reduced feeding activity only materializes after the copepod has ingested some cells, and so is likely mediated by substances released during processing of food in the gut.
Subsequent to this transition period the copepod keeps beating its feeding appendages intermittently and captures and ingests prey cells at a low rate, allowing the copepod to continuously sample the environment and - presumably - to pick up feeding at high rate if the prey environment changes. A similar behavior is observed in the copepod Acartia tonsa. This copepod modifies its appendage beat activity and feeding current production in response to the concentration and type (size, motility) of prey cells in the environment (Jonsson and Tiselius, 1990), allowing it to switch between feeding current feeding and ambush feeding. In the presence of toxic Karenia spp. cells it also (within $10 \mathrm{~min}$ ) reduces appendage beat activity to only sample the environment, and resumes more active feeding if the prey environment becomes favorable (Hong et al., 2012).

Some studies have demonstrated reduced growth and egg production rates (Colin and Dam, 2007; Dutz, 1998; Guisande et al., 2002; Roncalli et al., 2016; Sopanen et al., 2011; Teegarden et al., 2008) or elevated mortality (Avery et al., 2008; Sopanen et al., 2011) in copepods exposed to toxic algae compared to control algae. Such responses may be mediated by the behaviors considered above that both lead to reduced prey ingestion, or by the regurgitation of consumed algae, as described here for T. longicornis feeding on A. tamarense Alex2. From our video observations, most of the regurgitated cells were smashed and so it is impossible to quantify the exact amount of food lost through regurgitation, but it may be significant. Sykes and Huntley (1987) reported a similar observation of the copepod Calanus finmarchicus regurgitating Protoceratium reticulatum (=Gonyaulax grindleyi), and found that the copepod was unable to fill its gut, suggesting a 
significant reduction in net food intake. While the regurgitation response observed by Sykes and Huntley only occurred 45-120 min after initiation of feeding, the response reported here is immediate and specific to the cell just consumed.

All the prey aversion responses observed here, viz. reduced feeding activity, rejection of captured cells, and regurgitation of ingested cells, may all lead to reduced energy uptake, growth, and egg production of the copepod. The ecological and evolutionary implications of the responses differ in several important ways. First, a prey cue that leads to prey rejection, that is, a true feeding deterrent, is beneficial to the algal cell as it survives the interaction with the copepod, allows the copepod to continue to feed on competing but palatable cells, and may lead to the formation of a bloom. It is also easy to envisage how such feeding deterrent can evolve as it gives the individual cell a competitive advantage. Second, a cue that leads to reduced feeding activity, although beneficial to the compounds producer, may be equally beneficial to its competitors, and cheaters that do not pay the price of compound production may flourish. It appears not to be an evolutionary stable strategy and may not lead to the formation of a bloom of the compound producer. Thirdly, an ingested but regurgitated cell is not beneficial to the individual cell (it is dead), and although it may reduce grazing due to reduced growth or survival of the predators, it does so only on its sibling cells and equally on its competitors.

\subsection{Potential role of cellular toxin quantity and composition on copepod behavioral responses}

It is unclear from our results and from data in the literature exactly what elicits the very different behavioral responses in copepods exposed to the various strains of Alexandrium, except that it most likely is a chemical cue contained in or released by the cells.

With respect to PSTs, their mode of action in vertebrates is known to be a binding to voltage-gated sodium channels inhibiting action potential, nerve transmission, and ultimately muscle contraction (Cusick and Sayler, 2013), and it thus could be expected that voltage-gated sodium channels of invertebrates are likewise affected. Although a number of invertebrates retain and accumulate PSTs in their tissues, many species including a number of bivalve mollusks are - contrary to popular belief - not immune to PSTs (Gaines and Shumway, 1988; Kvitek and Beitler, 1991; Robineau et al., 1991). Paralytic shellfish toxins resistance in soft shell clams has been identified to be caused by a single mutation in the saxitoxin binding site in the sodium channel (Bricelj et al., 2005). Copepods have also been demonstrated to adapt to PSTs and become immune after some generations of exposure (Colin and Dam, 2007, 2004), but the mechanism of adaptation remains unknown. Like in Bivalves, sodium channel mutants have been identified in the copepod $A$. hudsonica, but these turned out not to account for achieved immunity in this copepod species (Finiguerra et al., 2015).

Considering the toxin composition in the PSTs containing strains used in our experiments, the most distinct response (in terms of ingestion rates) is found when fed on Alex 5 (reduced beating activity) followed by Alex2 (regurgitation) and with no response to AlexH5. This pattern of behavioral responses cannot be easily explained by cellular content or ingestion of total PSTs (in STXeq) (Table 2 and Fig. 3A). AlexH5 among all PST-producing strains tested had the highest cellular toxin content, both as total compounds per cell and when calculated as STX equivalents (Table 2), but failed to cause obvious copepod behavioral responses. The common conversion of all quantities of single congeners to one estimate of total toxicity (in STX eq) is justified by how toxic they are to humans, and thus Toxicity-EquivalentFactors based on the standard mouse bioassay (Munday, 2014) are used. It can be an reasonable assumption that relative potency of each single PST compound may vary dramatically for different sodium channel types even for vertebrate cells (Alonso et al., 2016) and it is unknown whether and how invertebrate sodium channels are differentially affected. Thus, copepod behavior might be related to single toxin compounds, and copepod behavior was indeed correlated with cell content and total ingestion of the STX molecule (Fig. 3B), suggesting that specifically STX plays an important role for the observed copepod behavioral changes. Such a view, however, is likely too simplistic, as all $A$. tamarense strains also had significant amounts of the nearly identical molecule neosaxitoxin (NEO). While Alex5 (reduced beating activity) also had the most STX and NEO when combined, AlexH5 (no effect) had more than Alex2 (regurgitation). So the observed behavior cannot be related to estimates of total STX + NEO ingestion (see Appendix Fig. 8-10). The inconclusive pattern of behavioral responses in our experiments aligns well with the results of the incubation experiments of (Teegarden et al., 2008): the very different feeding rates in 4 different species of copepods to Alexandrium spp. strains of different PST toxicity that they observed were unrelated to the level of total toxicity (as STX eq per cell) and only related to whether or not the cells were toxic. Thus, the resolution of the feeding response into the more diverse behavioral responses and the information on the composition of toxins reported here do not appear to provide clear answers to the identity and nature of the cues that are responsible for the responses.

The presence of lytic compounds also did not correlate with behavioral changes of $T$. longicornis. Allelochemicals from Alexandrium are assumed to primarily act destructively on the external plasma membrane and have been shown to have a high lysis potential for single protistan cells (Tillmann et al., 2008). Authors here for the first time provide evidence that these lytic compounds, at least at the concentrations applied in our experiments, do not affect the short term feeding behavior of $T$. longicornis.

The response of the copepod to one strain of A. pseudogonyaulax was also examined. This species has been described to produce the neurotoxin goniodomin A, but no PSTs. The A. pseudogonyaulax strain used in this study contained a dominant peak of a compound with the mass of goniodomin A and was the only strain that elicited strong prey rejection responses.

In conclusion, the higher resolution of the behavioral responses revealed by direct observations compared to incubation approaches has demonstrated a high degree of strain-specificity, not only in bulk grazing reduction but also in how grazing reduction is achieved. Our comparative approach of using a number of Alexandrium strains, which are considered toxic from a human health point of view, differing in the amount and type of toxins was successful in providing first evidence that goniodomin $\mathrm{A}$ plays a role as a true grazer deterrent. Moreover, there is no evidence that lytic compounds affect $T$. longicornis feeding behavior. On the other hand, behavioral response of $T$. longicornis to three PST-producing strains, even when acknowledging their differences in total amounts and PST profile, was too different to accept a universal role of PSTs in affecting T. longicornis feeding, and other substances may provide the cues for the diverse behavioral responses observed here. One promising avenue to pursue may be to combine directly observed responses with metabolic profiling of the phytoplankton as applied to resolve other plankton chemical cues (Selander et al., 2016).

\section{Acknowledgements}

Jiayi is supported by a PhD fellowship from China Scholarship Council and The Centre for Ocean Life is supported by the Villum Foundation.[SS] 


\section{Appendix A. Supplementary data}

Supplementary data associated with this article can be found, in the online version, at http://dx.doi.org/10.1016/j.hal.2016.11.020.

\section{References}

Alexander, J., Benford, D., Cockburn, A., Cravedi, J., Dogliotti, E., Domenico, A., Di Fernández-cruz, M.L., Fink-gremmels, J., Fürst, P., Galli, C., Grandjean, P., Gzyl, J., Heinemeyer, G., Johansson, N., Mutti, A., Schlatter, J., Leeuwen, R., Van Peteghem, C., 2009. Marine biotoxins in shellfish-summary on regulated marine biotoxins Scientific Opinion of the Panel on Contaminants in the Food Chain. EFSA J. 1306, 1-23.

Alonso, E., Alfonso, A., Vieytes, M.R., Botana, L.M., 2016. Evaluation of toxicity equivalent factors of paralytic shellfish poisoning toxins in seven human sodium channels types by an automated high throughput electrophysiology system. Arch. Toxicol. 90, 479-488. doi:http://dx.doi.org/10.1007/s00204-0141444-y.

Anderson, D.M., Alpermann, T.J., Cembella, A.D., Collos, Y., Masseret, E., Montresor, M., 2012. The globally distributed genus Alexandrium: Multifaceted roles in marine ecosystems and impacts on human health. Harmful Algae 14,10-35. doi: http://dx.doi.org/10.1016/j.hal.2011.10.012.

Avery, D.E., Altand, K.K., Dam, H.G., 2008. Sex-related differential mortality of a marine copepod exposed to a toxic dinoflagellate. Limnol. Oceanogr. 53, 2627 2635. doi:http://dx.doi.org/10.4319/lo.2008.53.6.2627.

Blossom, H.E., Daugbjerg, N., Hansen, P.J., 2012. Toxic mucus traps: a novel mechanism that mediates prey uptake in the mixotrophic dinoflagellate Alexandrium pseudogonyaulax. Harmful Algae 17, 40-53. doi:http://dx.doi.org/ 10.1016/j.hal.2012.02.010.

Blossom, H.E., Andersen, N.G., Rasmussen, S.A., Hansen, P.J., 2014. Stability of the intra- and extracellular toxins of Prymnesium parvum using a microalgal bioassay. Harmful Algae 32, 11-21. doi:http://dx.doi.org/10.1016/j. hal.2013.11.006.

Bricelj, V.M., Connell, L., Konoki, K., MacQuarrie, S.P., Scheuer, T., Catterall, W.A., Trainer, V.L., 2005. Sodium channel mutation leading to saxitoxin resistance in clams increases risk of PSP. Nature 434, 763-767. doi:http://dx.doi.org/10.1038/ nature03415.

Bruno, E., Andersen Borg, C.M., Kiørboe, T., 2012. Prey detection and prey capture in copepod nauplii. PLoS One 7, 1-8. doi:http://dx.doi.org/10.1371/journal. pone.0047906.

Burkholder, J.M., Glibert, P.M., 2006. Intraspecific variability: an important consideration in forming generalisations about toxigenic algal species. Afr. J. Mar. Sci. 28, 177-180. doi:http://dx.doi.org/10.2989/18142320609504143.

Cembella, A.D., 1998. Ecophysiology and metabolism of paralytic shellfish toxins in marine microalgae. In: Anderson, D.M., Cembella, A.D., Hallegraeff, G.M. (Eds.), Physiological Ecology of Harmful Algal Blooms, NATO-Advanced Study Institute Series, 41. Springer-Verlag, Heidelberg, pp. 381-403.

Colin, S.P., Dam, H.G., 2002. Latitudinal differentiation in the effects of the toxic dinoflagellate Alexandrium spp. on the feeding and reproduction of populations of the copepod Acartia hudsonica. Harmful Algae 1, 113-125. doi:http://dx.doi. org/10.1016/S1568-9883(02)00007-0.

Colin, S.P., Dam, H.G., 2004. Testing for resistance of pelagic marine copepods to a toxic dinoflagellate. Evol. Ecol. 18, 355-377. doi:http://dx.doi.org/10.1007/ s10682-004-2369-3.

Colin, S.P., Dam, H.G., 2007. Comparison of the functional and numerical responses of resistant versus non-resistant populations of the copepod Acartia hudsonica fed the toxic dinoflagellate Alexandrium tamarense. Harmful Algae 6, 875-882. doi:http://dx.doi.org/10.1016/j.hal.2007.05.003.

Cowles, T.J., Strickler, J.R., 1983. Characterization of feeding activity patterns in the planktonic copepod Centropages typicus Kroyer under various food conditions. Limnol. Oceanogr. 28, 106-115. doi:http://dx.doi.org/10.4319/lo.1983.28.1.0106.

Cusick, K.D., Sayler, G.S., 2013. An overview on the marine neurotoxin, saxitoxin: genetics, moleculartargets, methods of detection and ecological functions. Mar. Drugs 11, 991-1018. doi:http://dx.doi.org/10.3390/md11040991.

DeMott, W.R., Moxter, F., 1991. Foraging cyanobacteria by copepods: responses to chemical defense and resource abundance. Ecology 72, 1820-1834. doi:http:// dx.doi.org/10.2307/1940981.

Dutz, J., 1998. Repression of fecundity in the neritic copepod Acartia clausi exposed to the toxic dinoflagellate Alexandrium lusitanicum:relationship between feeding and egg production. Mar. Ecol. Prog. Ser. 175, 97-107. doi:http://dx.doi. org/10.3354/meps175097.

Engström-Öst, J., Viitasalo, M., Jónasdóttir, S., Repka, S., Sivonen, K., Koski, M., Schmidt, K., 2002. Calanoid copepods feed and produce eggs in the presence of toxic cyanobacteria Nodularia spumigena. Limnol. Oceanogr. 47, 878-885. doi: http://dx.doi.org/10.4319/lo.2002.47.3.0878.

Finiguerra, M., Avery, D.E., Dam, H.G., 2015. Determining the advantages, costs, and trade-offs of a novel sodium channel mutation in the copepod Acartia hudsonica to paralytic shellfish toxins (PST). PLoS One 10,1-23. doi:http:// dx.doi.org/10.1371/journal.pone.0130097.

Frangopulos, M., Guisande, C., Maneiro, I., Riveiro, I., Franco, J., 2000. Short-term and long-term effects of the toxic dinoflagellate Alexandrium minutum on the copepod Acartia clausi. Mar. Ecol. Prog. Ser. 203, 161-169. doi:http://dx.doi.org/ 10.3354/meps203161.
Gaines, L.F., Shumway, S.E., 1988. A compendium of the responses of bivalve moluscs to toxic dinoflagellates. J. Shellfish Res. 7, 623-628.

Gonçalves, R.J., Kiørboe, T., 2015. Perceiving the algae: how feeding-current feeding copepods detect their nonmotile prey. Limnol. Oceanogr. 60, 1286-1297. doi: http://dx.doi.org/10.1002/lno.10102.

Gonçalves, R.J., Van Someren Gréve, H., Couespel, D., Kiørboe, T., 2014. Mechanisms of prey size selection in a suspension-feeding copepod, Temora longicornis. Mar. Ecol. Prog. Ser. 517, 61-74. doi:http://dx.doi.org/10.3354/meps11039.

Granéli, E., Hansen, P.J., 2006. Allelopathy in harmful algae: a mechanism to compete for resources? Ecol. Harmful Algae 189-201.

Guisande, C., Frangópulos, M., Carotenuto, Y., Maneiro, I., Riveiro, I., Ruth Vergara, A., 2002. Fate of paralytic shellfish poisoning toxins ingested by the copepod Acartia clausi. Mar. Ecol. Prog. Ser. 240, 105-115. doi:http://dx.doi.org/10.3354/ meps240105.

Hong, J., Talapatra, S., Katz, J., Tester, P. a., Waggett, R.J., Place, A.R., 2012. Algal toxins alter copepod feeding behavior. PLoS One 7,1-10. doi:http://dx.doi.org/10.1371/ journal.pone.0036845.

Howard, M.D.A., Smith, G.J., Kudela, R.M., 2009. Phylogenetic relationships of yessotoxin-producing dinoflagellates, based on the large subunit and internal transcribed spacer ribosomal DNA domains. Appl. Environ. Microbiol. 75, 54 63. doi:http://dx.doi.org/10.1128/AEM.00818-08.

Hsia, M.H., Morton, S.L., Smith, L.L., Beauchesne, K.R., Huncik, K.M., Moeller, P.D.R., 2006. Production of goniodomin A by the planktonic, chain-forming dinoflagellate Alexandrium monilatum (Howell) Balech isolated from the Gulf Coast of the United States. Harmful Algae 5, 290-299. doi:http://dx.doi.org/ 10.1016/j.hal.2005.08.004.

Huntley, M., Sykes, P., Rohan, S., Marin, V., 1986. Chemically-mediated rejection of dinoflagellate prey by the copepods Calanus pacificus and Paracalanus parvus: mechanism, occurrence and significance. Mar. Ecol. Prog. Ser. 28, 105-120. doi: http://dx.doi.org/10.3354/meps028105.

Jonsson, P., Tiselius, P., 1990. Feeding behaviour, prey detection and capture efficiency of the copepod Acartia tonsa feeding on planktonic ciliates. Mar. Ecol. Prog. Ser. 60, 35-44. doi:http://dx.doi.org/10.3354/meps060035.

Jonsson, P.R., Pavia, H., Toth, G., 2009. Formation of harmful algal blooms cannot be explained by allelopathic interactions. Proc. Natl. Acad. Sci. U. S. A. 106, $11177-$ 11182. doi:http://dx.doi.org/10.1073/pnas.0900964106.

Klein, G., Martin, J.L., Kaczmarska, I., 2010. Biological synopsis of phytoplankton new to the Bay of Fundy. Can. Manuscr. Rep. Fish. Aquat. Sci. 2919, 1-37 (v+).

Kozlowsky-Suzuki, B., Karjalainen, M., Lehtiniemi, M., Engström-Öst, J., Koski, M., Carlsson, P., 2003. Feeding, reproduction and toxin accumulation by the copepods Acartia bifilosa and Eurytemora affinis in the presence of the toxic cyanobacterium Nodularia spumigena. Mar. Ecol. Prog. Ser. 249, 237-249. doi: http://dx.doi.org/10.3354/meps249237.

Kremp, A., Tahvanainen, P., Litaker, W., Krock, B., Suikkanen, S., Leaw, C.P., Tomas, C. 2014. Phylogenetic relationships, morphological variation, and toxin patterns in the Alexandrium ostenfeldii (Dinophyceae) complex: implications for species boundaries and identities. J. Phycol. 50, 81-100. doi:http://dx.doi.org/10.1111/ jpy.12134.

Krock, B., Borel, C.M., Barrera, F., Tillmann, U., Fabro, E., Almandoz, G.O., Ferrario, M. Garz??n Cardona, J.E., Koch, B.P., Alonso, C., Lara, R., 2015. Analysis of the hydrographic conditions and cyst beds in the San Jorge Gulf, Argentina, that favor dinoflagellate population development including toxigenic species and their toxins. J. Mar. Syst. 148, 86-100. doi:http://dx.doi.org/10.1016/j. jmarsys.2015.01.006.

Kvitek, R., Beitler, M., 1991. Relative insensitivity of butter clam neurons to saxitoxin; a pre-adaptation for sequestering paralytic shellfish poisoning toxins as a chemical defense. Mar. Ecol. Prog. Ser. 69, 47-54. doi:http://dx.doi.org/ $10.3354 /$ meps069047.

Legrand, C., Rengefors, K., Fistarol, G.O., Granéli, E., 2003. Allelopathy in phytoplankton - biochemical, ecological and evolutionary aspects. Phycologia 42, 406-419. doi:http://dx.doi.org/10.2216/i0031-8884-42-4-406.1.

Ma, H., Krock, B., Tillmann, U., Cembella, A., 2009. Preliminary characterization of extracellular allelochemicals of the toxic marine dinoflagellate Alexandrium tamarense using a Rhodomonas salina bioassay. Mar. Drugs 7, 497-522. doi: http://dx.doi.org/10.3390/md7040497.

Moestrup, Ø., Akselmann, R., Fraga, S., Hansen, G., Hoppenrath, M., Iwataki, M. Komárek, J., Larsen, J., Lundholm, N., Zingone, A., 2009. IOC-UNESCO Taxonomic Reference List of Harmful Micro Algae [WWW Document]. Accessed at http:// www.marinespecies.org/hab on 2016-05-24.

Munday, R., 2014. Toxicology of seafood toxins: a critical review. Seafood Freshwater Toxins: Pharmacol. Physiol. Detect. 197-290. doi:http://dx.doi.org/10.1201/ b16662-10.

Murakami, M., Makabe, K., Yamaguchi, K., Konosu, S., Wälchli, M.R., 1988. Goniodomin A, a novel polyether macrolide from the dinoflagellate Goniodoma pseudogoniaulax. Tetrahedron Lett. 29, 1149-1152. doi:http://dx.doi.org/ 10.1016/S0040-4039(00)86674-5.

Murakami, M., Okita, Y., Matsuda, H., Okino, T., Yamaguchi, K., 1998. From the dinoflagellate Alexandrium hiranoi. Phytochemistry 48, 85-88. doi:http://dx. doi.org/10.1016/S0031-9422(97)00756-5.

Paffenhöfer, G.A., Strickler, J.R., Alcaraz, M., 1982. Suspension-feeding by herbivorous calanoid copepods: a cinematographic study. Mar. Biol. 67, 193-199. doi http://dx.doi.org/10.1007/BF00401285.

Robineau, B., Gagné, J.A., Fortier, L., Cembella, A.D., 1991. Potential impact of a toxic dinoflagellate (Alexandrium excavatum) bloom on survival of fish and crustacean larvae. Mar. Biol. 108, 293-301. doi:http://dx.doi.org/10.1007 BF01344344. 
Roncalli, V., Turner, J.T., Kulis, D., Anderson, D.M., Lenz, P.H., 2016. The effect of the toxic dinoflagellate Alexandrium fundyense on the fitness of the calanoid copepod Calanus finmarchicus. Harmful Algae 51, 56-66. doi:http://dx.doi.org 10.1016/j.hal.2015.11.003.

Sala-Pérez, M., Alpermann, T.J., Krock, B., Tillmann, U., 2016. Growth and bioactive secondary metabolites of arctic Protoceratium reticulatum (Dinophyceae). Harmful Algae 55, 85-96. doi:http://dx.doi.org/10.1016/j.hal.2016.02.004.

Schultz, M., Kiørboe, T., 2009. Active prey selection in two pelagic copepods feeding on potentially toxic and non-toxic dinoflagellates. J. Plankton Res. 31, 553-561. doi:http://dx.doi.org/10.1093/plankt/fbp010.

Selander, E., Thor, P., Toth, G., Pavia, H., 2006. Copepods induce paralytic shellfish toxin production in marine dinoflagellates. Proc. R. Soc. B 273, 1673-1680. doi: http://dx.doi.org/10.1098/rspb.2006.3502.

Selander, E., Fagerberg, T., Wohlrab, S., Pavia, H., 2012. Fight and flight in Dinoflagellates? Kinetics of simultaneous grazer-induced responses in Alexandrium tamarense. Limnol. Oceanogr. 57, 58-64. doi:http://dx.doi.org/ 10.4319/lo.2012.57.1.0058.

Selander, E., Heuschele, J., Nylund, G.M., Pohnert, G., Pavia, H., Bjærke, O., PenderHealy, L.A., Tiselius, P., Kiørboe, T., 2016. Solid phase extraction and metabolic profiling of exudates from living copepods. PeerJ 4, e1529. doi:http://dx.doi.org/ $10.7717 /$ peerj.1529.

Sopanen, S., Setälä, O., Piiparinen, J., Erler, K. Kremp, A., 2011. The toxic dinoflagellate Alexandrium ostenfeldii promotes incapacitation of the calanoid copepods Eurytemora affinis and Acartia bifilosa from the northern Baltic Sea. J Plankton Res. 33, 1564-1573. doi:http://dx.doi.org/10.1093/plankt/fbr052.

Suikkanen, S., Kremp, A., Hautala, H., Krock, B., 2013. Paralytic shellfish toxins or spirolides? The role of environmental and genetic factors in toxin production of the Alexandrium ostenfeldii complex. Harmful Algae 26, 52-59. doi:http://dx. doi.org/10.1016/j.hal.2013.04.001.

Sykes, P.F., Huntley, M.E., 1987. Acute physiological reactions of Calanus pacificus to selected dinoflagellates: direct observations. Mar. Biol. 94, 19-24. doi:http://dx. doi.org/10.1007/BF00392895.

Teegarden, G.J., Campbell, R.G., Anson, D.T., Ouellett, A., Westman, B.A., Durbin, E.G., 2008. Copepod feeding response to varying Alexandrium spp. cellular toxicity and cell concentration among natural plankton samples. Harmful Algae 7, 3344. doi:http://dx.doi.org/10.1016/j.hal.2007.05.010.

Teegarden, G.J., 1999. Copepod grazing selection and particle discrimination on the basis of PSP toxin content. Mar. Ecol. Prog. Ser. 181, 163-176. doi:http://dx.doi. org/10.3354/meps181163.

Tillmann, U., Hansen, P.J., 2009. Allelopathic effects of Alexandrium tamarense on other algae: evidence from mixed growth experiments. Aquat. Microb. Ecol. 57, 101-112. doi:http://dx.doi.org/10.3354/ame01329.

Tillmann, U., John, U., 2002. Toxic effects of Alexandrium spp. on heterotrophic dinoflagellates: an allelochemical defence mechanism independent of PSPtoxin content. Mar. Ecol. Prog. Ser. 230, 47-58. doi:http://dx.doi.org/10.3354/ meps230047.

Tillmann, U., Alpermann, T., John, U., Cembella, A., 2008. Allelochemical interactions and short-term effects of the dinoflagellate Alexandrium on selected photoautotrophic and heterotrophic protists. Harmful Algae 7, 52-64. doi: http://dx.doi.org/10.1016/j.hal.2007.05.009.

Tillmann, U., Alpermann, T.L., da Purificação, R.C., Krock, B., Cembella, A., 2009. Intra-population clonal variability in allelochemical potency of the toxigenic dinoflagellate Alexandrium tamarense. Harmful Algae 8, 759-769. doi:http:// dx.doi.org/10.1016/j.hal.2009.03.005.

Tiselius, P., Saiz, E., Kiørboe, T., 2013. Sensory capabilities and food capture of two small copepods, Paracalanus parvus and Pseudocalanus sp. Limnol. Oceanogr. 58, 1657-1666. doi:http://dx.doi.org/10.4319/lo.2013.58.5.1657.

Turner, J.T., Tester, P.A., 1997. Toxic marine phytoplankton, zooplankton grazers, and pelagic food webs. Limnol. Oceanogr. 42, 1203-1213. doi:http://dx.doi.org/ 10.4319/lo.1997.42.5_part_2.1203.

Turner, J.T., 2014. Planktonic marine copepods and harmful algae. Harmful Algae 32, 81-93. doi:http://dx.doi.org/10.1016/j.hal.2013.12.001.

Vanderploeg, H.A., Paffenhöfer, G.-A., Liebig, J.R., 1990. Concentration-Variable interactions between calanoid copepods and particles of different food quality: observations and hypotheses. Behavioural Mechanisms of Food Selection. Springer, Berlin Heidelberg, pp. 595-613. doi:http://dx.doi.org/10.1007/978-3642-75118-9_29. 